\title{
Association of Hand Length with Height in Nigerian School Children
}

\author{
A. O. Ibegbu (Corresponding author) \\ Department of Human Anatomy, Faculty of Medicine \\ Ahmadu Bello University Zaria, Kaduna State, Nigeria. 81006 \\ Tel: 234-803-218-8042 E-mail: aoibegbu@yahoo.com \\ E. T. David \\ Department of Human Anatomy, Faculty of Medicine \\ Ahmadu Bello University Zaria, Kaduna State, Nigeria. 81006 \\ E-mail: henyholah@facebook.com
}

\section{W.O. Hamman}

Department of Human Anatomy, Faculty of Medicine;

Ahmadu Bello University Zaria, Kaduna State, Nigeria. 81006.

Tel: 234-806-230-3007Ｅ-mail: wohamman@abu.edu.ng

U.E. Umana

Department of Human Anatomy, Faculty of Medicine Ahmadu Bello University Zaria, Kaduna State, Nigeria. 81006

Tel: 234-803-701-5363Ｅ-mail: ueumana@yahoo.com

\section{S. A. Musa}

Department of Human Anatomy, Faculty of Medicine Ahmadu Bello University Zaria, Kaduna State, Nigeria. 81006

Tel: 234-815-462-5756Ｅ-mail: sundaymusa@gmail.com 
Received: January 11, 2013 Accepted: January 25, 2013

doi:10.5296/jbls.v4i2.3025

URL: http://dx.doi.org/10.5296/jbls.v4i2.3025

\begin{abstract}
The study of the anthropometric characteristics of 600 normal Nigeria School Children of ages between 5-10 years of Gbagyi tribe of Abuja, with no obvious deformities or previous history of trauma to the hand was undertaken. The study of these children, males ( $n=300)$ with mean age of $7.10 \pm 1.98$, and females $(n=300)$ with mean age of $7.68 \pm 1.86$ was investigated. The anthropometric characteristics of their height, age, weight, hand length, and body mass indices were measured, analysed statistically for any significant difference, and correlation between the parameters studied. The results show some significant differences between the anthropometric parameters and a significant correlation $(\leq 0.001)$ between the height and hand length, and other parameters in both males and females. The study derived a linear regression and a multiple linear regression equations for Gbagyi School children of Nigeria from which height, age, weight, hand length and body mass index could be predicted if one factor is known. The results from the present study show that there was a positive correlation between height and hand length and other parameters indicating that height could be predicted using hand length, age, weight and body mass index among Gbagyi school children of Abuja-Nigeria.
\end{abstract}

Keywords: Height, Hand Length, Anthropometry, School Children, Nigeria, Gbagyi tribe

\title{
1. Introduction
}

Estimation of the body size such as height and weight are required for assessment of growth, nutritional status, calculating body surface area and predicting pulmonary function of children (Gauld et al., 2004; Amirsheybani et al., 2000). Measurement of height is important for determination of basic energy requirement, standardization, and measures of physical capacity and for adjusting drug dosages (Jalzem and Gledhill, 1993). However in some situations the exact height cannot be determined directly because the patient is unable to stand as a result of neuromuscular weakness, deformities of axial skeleton such as kyphosis, lordosis, scoliosis, lost of lower limbs and in patients who have undergone amputations (Duyar and Pelin, 2003; Duyar et al., 2006). In such patients, height does not reflect the body size and the use of height measurements in prediction equation is likely to produce error. For example in scoliosis patients, the predicted spirometric values were underestimated when the measured body was used and under such circumstances, an estimate of height has to be computed based on another body parameters (Amirsheybani et al., 2001; De Mendonca, 2000).

The hand length was found to be the most reliable alternative and the hand can be used as a basis for estimating age-related loss in height. The length of the body while alive is one of the key parameters established in the course of identification of unknown skeletal remains (Hauser et al., 2005; Auberch and Ruff, 2004). Stature provides insight into various features of a population including nutritional health and genetics. Stature is considered as one of the parameters for personal identification (Krishan and Sharma, 2007; Anitie, 2007). 


\section{Mll Macrothink}

Journal of Biology and Life Science

ISSN 2157-6076

2013, Vol. 4, No. 2

The most important applications of anthropology at field level include biological anthropology, epidemiology, clinical application and in metabolic research (Bidmos, 2006; Bidmos, 2009). The hand length could be used to predict body weight status and body surface area independent of the sex of the individual (Bidmos, 2009). Correlation between hand length and foot length has also been studied and that if the hand length is known, the foot length can be predicted and vice-versa. Hand length has been shown to be a reliable and precise means in predicting the height of an individual (Gauld and Rakhir, 1996; Ebites et al., 2000).

In forensic investigations, the dimensions of the hand and foot have been used in the determination of sex, age, stature of an individual. Stature reconstruction is important as it provides forensic anthropological estimation of the height of a person in the living state which plays a vital role in the identification of individual remains (Bhatnagar et al., 1984; Boldsen, 1984). Intact long limb bones have been used in the derivation of regression equations for stature assessment in different population groups. Anthropologist observes and compared the relation between body and segments to highlight variations between and within groups. Determination of stature is a major concern in forensic medicine and forensic anthropology (Fessler et al., 2005). The bone area values at different sites strongly correlates to muscle strength and also correlate to body size; height, weight, lean mass, fat mass and body mass index (BMI) (Fessler et al, 2005). It is commonly accepted that standards for skeletal identification vary among different populations and the standard for one population may not be used for another (Thakur and Rai, 1987; Iscan, 1988).

Establishing personal identification of the victims is often required and the estimation of stature from extremities and their parts plays an important role in identifying the dead in forensic examinations (Nath et al., 1998; Munoz et al., 2000). When the health risk is defined in terms of body size, Western Caucasian standards have, by default become the international standard. Although by far the most long term data available on health risks are from Caucasian subjects, there is mounting evidence that these Western standards may not be applicable to Africans and Asians (Krishan and Sharma, 2007). The reconstruction of body stature has been a subject of study since the beginning of the nineteenth century in the specialized areas of forensic anthropology which deals with the application of methods and techniques of analysing skeletal remains (Trotter and Glesser, 1958; Iscan, 1988; Iscan, 2001).

The aim of the present study was to investigate the association of hand length with height and to show if height could be predicted using hand length measurements in Nigerian School Children of Gbagyi ethic group.

\section{Materials and Methods}

\subsection{Subjects}

This study was carried out from three different Local Authority Primary School namely; Byazhin, Aziyapi, Kubwa II all in Bwari Local Government Area of Abuja-Nigeria, belonging to the same Gbagyi ethnic group in June, 2011. The sample consists of 300 males and 300 females with each school having 100 males and 100 females with no known physical deformities between the ages of 5-10 years. The inclusion criteria include that participants 
must be boys and girls between the ages of 5-10 years of age, of Gbagyi tribe from both parents and grandparents within Abuja Area of Nigeria and without any known Physical or Mental deformity.

\subsection{Methodology}

The demographic data of the subjects collected include the age in years, name, place of birth, parental and grandparental origin were completed in the questionnaire. Standing height, hand length and weight measurements were done taken.

Standing height was measured to the nearest centimetres $(\mathrm{cm})$ using a Stadiometer with subject standing erect on a horizontal resting plane bare footed having the palms of the hands turned inward and the finger pointing downwards and the height was then converted to the nearest meters $(\mathrm{m})$. The height was measured from the sole of the feet to the vertex of the head as recommended by International Biological Program (Mauthausem and Gusen, 1959; WHO, 1995).

The body weights of the subjects were taken using the mechanical weighing balance to the nearest kg according to the standard procedures (Yyagi et al., 1999; Menezes and Khany, 1998). BMI was calculated by dividing weight by converted height squared (weight/height squared $\left(\mathrm{kg} / \mathrm{m}^{2}\right)$ ) (WHO, 1995; Reeves et al., 1996). Body Mass Index (BMI) is a number calculated from a child's weight and height, and is a reliable indicator of body fatness for most children and teens. The hand length was measured with a calibrated non stretch tape from distal crease to the tip of the middle finger in extension as described by Amirsheybani et al. (2001). The measurements and readings from each subject were taken twice and recorded and if the two measurements and readings for each parameter agreed within 0.4 ranges the average was taken as the best estimate for the true value. When the two initial measures did not satisfy the 0.4 range criteria, two additional measurements and readings were made and the mean of the closest records was used as the best estimate (Reeves et al., 1996).

\subsection{Statistical Analysis}

Data was expressed as mean \pm standard deviation $( \pm \mathrm{SD})$. Pearson's correlation analysis was used to determine the strength of the relationship between the parameters studied. Students' T-test was used to test the significant levels between the body proportions studied both in males and females. Differences were declared significant when $\mathrm{P}-$ value is less than $0.05(\mathrm{P} \leq$ 0.05 ) and correlation exist when $\mathrm{P} \leq 0.001$. To investigate the utility of hand length, weight, age and BMI in height estimation, linear and multiple linear regression analysis were used.

\section{Results}

The results from the present study show the mean and standard deviation of height in male Children was $1.20 \pm 0.12 \mathrm{~m}$, while the mean and standard deviation of age, hand length, weight, and body mass index are shown in Table 1. The mean value for height in female Children was $1.21 \pm 0.12 \mathrm{~m}$, the mean of other variables; age, hand length, weight, and body mass index are shown in Table 2. There was significant difference $(\mathrm{P} \leq 0.05)$ between male and female School 
children in age, weight, but there was no significant difference $(\mathrm{P} \leq 0.05)$ in height, hand length, between the male and female School Children of Gbagyi tribe of Abuja-Nigeria.

The results in Table 3 show the mean and standard deviation of height, weight, hand length and BMI of each age group in both males and females. The results show that height, weight, hand length and BMI was significantly increased with age of the Gbagyi school children of Nigeria in both males and females $(\mathrm{P} \leq 0.05)$. This shows that there is a proportional relationship between age and the parameters studied and an age dependent increase in height, hand length, and an age dependent significant increase in weight and BMI in males $(\mathrm{P} \leq 0.05)$ except for $\mathrm{BMI}$ in which there was a decrease in ages 8 and 9 years which was not statistically significant. While the females show an age dependent significant increase also in height, hand length, weight and BMI, except for the age 9 years in which BMI was not significantly decreased $(\mathrm{P} \leq$ $0.05)$.

The result in Table 4 shows the correlation matrix of the anthropometric parameters studied. The result shows a 2-tailed correlation $(\mathrm{P} \leq 0.001)$ between height and hand length $(\mathrm{r}=0.706$; $0.703)$, age $(\mathrm{r}=0.820 ; 0.738)$, weight $(\mathrm{r}=0.827 ; 0.805)$ and BMI $(\mathrm{r}=0.164 ; 0.030)$ in males and females respectively. There was a 2-tailed correlation $(\mathrm{p} \leq 0.001)$ between height and hand length and with age $(r=0.778)$, weight $(r=0.705)$ and BMI $(r=0.894)$ in both male and female school children of Gbagyi tribe of Abuja Nigeria.

The result in Table 5 shows the linear regression of height $(\mathrm{m})$ from age (years), weight $(\mathrm{kg})$, hand length $(\mathrm{cm})$ and BMI $\left(\mathrm{kg} / \mathrm{m}^{2}\right)$ of the male and female school children of Gbagyi tribe of Abuja. The table shows the standard error of estimate (SEE) not more than $0.099 \mathrm{~m}$ and $0.091 \mathrm{~m}$ for the prediction of height in males and females respectively, and for the total not more than $0.095 \mathrm{~m}$. The linear regression equation for estimation of height from age (years), weight, hand length and BMI shows there was a positive correlation $(\mathrm{p} \leq 0.001)$ between height and other parameters studied.

The result in Table 6 shows the multiple regression equation for estimation of height from age (years), weight, hand length and BMI. The multiple linear regressions show a positive correlation $(\mathrm{P} \leq 0.001)$ of height with the other parameters used, but regression equation for the estimation of height from BMI shows no positive correlation of BMI with height.

Table 1. Anthropometric measurements in male and female children of Gbagyi tribe of Abuja-Nigeria

\begin{tabular}{|llllc|}
\hline & Males & Range & Females & Range \\
\hline & $\mathrm{N}=300$ & Min-Max & $\mathrm{N}=300$ & Min-Max \\
\hline Age $(\mathrm{Yrs})$ & $7.10 \pm 1.98$ & $5.0-10.0$ & $7.68 \pm 1.86^{*}$ & $5.0-10$ \\
\hline Height $(\mathrm{m})$ & $1.20 \pm 0.12$ & $1.0-1.51$ & $1.21 \pm 0.12$ & $0.99-1.50$ \\
\hline weight $(\mathrm{kg})$ & $22.53 \pm 6.14$ & $11.0-39.0$ & $23.77 \pm 5.91^{*}$ & $11.0-37.0$ \\
\hline Hand length $(\mathrm{cm})$ & $14.06 \pm 1.80$ & $11.0-19.0$ & $14.30 \pm 1.85$ & $11.0-19.0$ \\
\hline Body mass index & $15.49 \pm 2.45$ & $8.77-26.63$ & $16.11 \pm 2.59^{*}$ & $8.61-26.93$ \\
\hline
\end{tabular}

$* \mathrm{P} \leq 0.05$ : Shows there was increased statistical significant difference 


\section{Ml Macrothink}

Journal of Biology and Life Science

ISSN 2157-6076

2013, Vol. 4, No. 2

Table 2. Anthropometric parameters used according to age groups in male children of Gbagyi tribe of Abuja

\begin{tabular}{|l|l|l|l|l|l|l|}
\hline \multicolumn{7}{|c|}{ Males } \\
\hline Age groups (years) & 5 & 6 & 7 & 8 & 9 & 10 \\
\hline $\mathrm{N}$ & 96 & 60 & 26 & 22 & 32 & 65 \\
\hline Height $(\mathrm{m})$ & $1.09 \pm 0.06$ & $1.16 \pm 0.06$ & $1.20 \pm 0.05$ & $1.23 \pm 0.07$ & $1.29 \pm 0.08$ & $1.34 \pm 0.09^{*}$ \\
\hline Weight $(\mathrm{kg})$ & $7.07 \pm 2.7$ & $19.77 \pm 3.39$ & $24.62 \pm 3.75$ & $24.96 \pm 4.45$ & $26.88 \pm 4.38$ & $29.25 \pm 4.78$ \\
\hline Handlength $(\mathrm{cm})$ & $12.77 \pm 1.2$ & $13.35 \pm 1.22$ & $14.04 \pm 1.37$ & $14.96 \pm 1.70$ & $14.93 \pm 1.16$ & $15.86 \pm 1.51^{*}$ \\
\hline BMI $\left(\mathrm{kg} / \mathrm{m}^{2}\right)$ & $14.50 \pm 1.97$ & $14.73 \pm 2.28$ & $17.04 \pm 2.48$ & $16.47 \pm 2.40$ & $16.17 \pm 2.64$ & $16.37 \pm 2.38^{*}$ \\
\hline
\end{tabular}

$* \mathrm{P} \leq 0.05$ : Shows there is increase significant difference

Table 3. Anthropometric parameters used according to age groups in female children of Gbagyi tribe of Abuja.

\begin{tabular}{|l|l|l|l|l|l|l|}
\hline \multicolumn{7}{|c|}{ Females } \\
\hline Age $(\mathrm{yrs})$ & 5 & 6 & 7 & 8 & 9 & 10 \\
\hline $\mathrm{N}$ & 55 & 48 & 30 & 35 & 48 & 74 \\
\hline Height $(\mathrm{m})$ & $1.08 \pm 0.05$ & $1.14 \pm 0.07$ & $1.17 \pm 0.07$ & $1.21 \pm 0.08$ & $1.27 \pm 0.07$ & $1.32 \pm 0.11^{*}$ \\
\hline Weight $(\mathrm{kg})$ & $17.27 \pm 3.41$ & $19.94 \pm 3.98$ & $22.57 \pm 4.57$ & $23.98 \pm 3.71$ & $25.75 \pm 3.21$ & $30.16 \pm 3.99^{*}$ \\
\hline HandLth $(\mathrm{cm})$ & $12.42 \pm 1.21$ & $13.44 \pm 1.44$ & $13.60 \pm 1.52$ & $14.76 \pm 1.35$ & $15.13 \pm 1.42$ & $5.94 \pm 1.50^{*}$ \\
\hline BMI $\left(\mathrm{kg} / \mathrm{m}^{2}\right)$ & $14.75 \pm 2.81$ & $15.25 \pm 1.84$ & $16.37 \pm 2.81$ & $16.58 \pm 2.53$ & $15.99 \pm 1.52$ & $17.37 \pm 2.70^{*}$ \\
\hline
\end{tabular}

$* \mathrm{P} \leq 0.05$ : Shows there is increase significant difference

Table 4. Correlation Matrix of the anthropometric parameters used among the school children of Gbagyi tribe of Abuja

\begin{tabular}{|c|c|c|c|c|c|c|}
\hline Population & Parameters & Ages & weight & leight & hand length & BMI \\
\hline \multirow[t]{5}{*}{ Boys $(\mathrm{N}=300)$} & Ages & & & $0.820 * *$ & $0.671 * *$ & \\
\hline & Weight & & & $.827 * *$ & $0.683 * *$ & $0.682 * *$ \\
\hline & Height & $0.820 * *$ & $0.827 * *$ & & $0.706^{* *}$ & $0.164 *$ \\
\hline & Hand length & $0.671 * *$ & $0.683^{* *}$ & $0.706^{* *}$ & & $0.300 *$ \\
\hline & BMI & & $0.682 * *$ & $0.164 *$ & $0.300 * *$ & \\
\hline \multirow[t]{5}{*}{ Girls $(N=300)$} & Ages & & & $0.738 * *$ & $0.650 * *$ & \\
\hline & Weight & & & $0.805^{* *}$ & $0.708 * *$ & $0.607 * *$ \\
\hline & Height & $0.738 * *$ & $0.805 * *$ & & $0.703 * *$ & $0.30 * *$ \\
\hline & Hand length & $0.650 * *$ & $0.708 * *$ & $0.703 * *$ & & $0.284 *$ \\
\hline & BMI & & $0.607 * *$ & & & \\
\hline \multirow[t]{5}{*}{ Total $(\mathrm{N}=600)$} & Ages & & & $0.778 * *$ & & \\
\hline & Weight & & & $0.705^{* *}$ & & \\
\hline & Height & $0.778 * *$ & $0.705^{* *}$ & & $0.816 * *$ & $0.894 * *$ \\
\hline & Hand length & & & $0.816 * *$ & & \\
\hline & BMI & & & $0.894 * *$ & & \\
\hline
\end{tabular}

Table 4 shows the level of correlation between parameters studied in school children of Gbagyi tribe of Abuja. P < $0.001 * *$ shows there is a high correlation between the parameters. * shows there is low correlation between the parameters. 
Table 5. Linear regression of height $(m)$ in male $(n=300)$ and female $(n=300)$ from the parameters used among the school children of Gbagyi tribe of Abuja.

\begin{tabular}{|c|c|c|c|}
\hline \multicolumn{4}{|l|}{ Sample population: Males $(\mathrm{N}=300)$} \\
\hline Ht \& Age: Height $=0.849+0.0490$ age & 0.068 & 0.672 & $<0.001$ \\
\hline Ht \& Wt: Height $=0.838+0.0159 \mathrm{Wt}$ & 0.067 & 0.683 & $<0.001$ \\
\hline Ht \& Hl: Height $=0.545+0.0464 \mathrm{Hl}$ & 0.084 & 0.498 & $<0.001$ \\
\hline Ht\& BMI: Height $=1.07+0.00791 \mathrm{BMI}$ & 0.012 & 0.164 & $<0.001$ \\
\hline \multicolumn{4}{|l|}{ Females $(\mathrm{N}=300)$} \\
\hline Ht \& Age Height $=0.848+0.0469$ Age & 0.080 & 0.545 & $<0.001$ \\
\hline Ht \& Wt Height $=0826+0.0161 \mathrm{Wt}$ & 0.070 & 0.648 & $<0.001$ \\
\hline Ht \& Hl Height $=0.568+0.0448 \mathrm{Hl}$ & 0.084 & 0.494 & $<0.001$ \\
\hline Ht \& BMI Height $=1.19+0.00136 \mathrm{BMI}$ & $0.012 \quad 0.30$ & 0.09 & $<0.001$ \\
\hline \multicolumn{4}{|l|}{ Total sample $(\mathrm{N}=600)$} \\
\hline \multicolumn{2}{|c|}{ Ht \& Age: Height $=0.852261+0.0473903$ Age 0.074} & \multicolumn{2}{|c|}{$0.778 \quad 0.604<0.001$} \\
\hline \multicolumn{4}{|c|}{ Ht \& Wt: Height $=0.833852+0.0159312 \mathrm{Wt} \quad 0.069 \quad 0.705 \quad 0.497<0.001$} \\
\hline \multicolumn{4}{|c|}{$\begin{array}{llll}\text { Ht \& Hl: Height }=0.556396+0.0455739 H l & 0.084 & 0.816 & 0.665<0.001\end{array}$} \\
\hline Ht \& BMI: Height $=1.12888+0.00466671$ & 3MI 0.012 & 0.894 & $0.8<0.001$ \\
\hline
\end{tabular}

Table 5 shows the predictive equation of height from the parameters used $\mathrm{Ht}=\mathrm{Height}, \mathrm{Wt}=$ weight, $\mathrm{Hl}=\mathrm{hand}$ length, $\mathrm{Cc}=$ Chest circumference, $\mathrm{MUAC}=$ mid upper arm circumference, $\mathrm{BMI}=$ body mass index.

Table 6. Multiple linear Regression of height $(\mathrm{m})$ from the dimensions used in male and female children of Gbagyi tribe of Abuja.

\begin{tabular}{|lccc|}
\hline $\begin{array}{l}\text { Multiple parameter } \\
(\mathrm{N}=300)\end{array}$ & Predictive equation for height & SEE & P value \\
\hline Wt \& Age (Males) & $\mathrm{Ht}=0.800+0.00919 \mathrm{wt}+0.0267 \mathrm{age}$ & 0.058 & $<0.001$ \\
\hline Wt \& Age (Females) & $\mathrm{Ht}=0.790+0.0116 \mathrm{wt}+0.0186 \mathrm{age}$ & 0.067 & $<0.001$ \\
\hline
\end{tabular}

Table 6 shows the predictive equation of height from the parameters used $\mathrm{Ht}=\mathrm{Height}, \mathrm{Wt}=$ weight, $\mathrm{Hl}=\mathrm{hand}$ length, BMI=body mass index

\section{Discussion}

The result of the present study showed that the dimension of hand length, age, weight and body mass index can be associated with height and can be used in the estimation of height. The parameters studied, showed a significant correlation with height in both male and female Nigerian School Children of Gbagyi tribe of Abuja. Hence these could be used by law enforcement agents and forensic scientists in the identification of the fragmentary and 
dismembered human remains in Nigerian school children of Gbagyi descent of Abuja. Since it has been established that long bones are the most appropriate specimen for height evaluation and estimation (Iscan, 1988; Jasuga et al., 2004), hand length was chosen for this study as it is part of the long bones of the body. It has been shown in this study that there was a significant correlation between height and hand length and with age, weight and BMI in male and female of Nigerian school children of Gbagyi tribe of Abuja.

The use of anthropometric methods is available in case of athletes in which the bone area values at different sites of the body are strongly related to muscle strength and parameters related to body size such as height, weight, lean mass, fat mass and body mass index according to Ruff, (2000) and Jasuga et al., (2004). Thus morphometric estimation of body mass from skeletal size appears to work reasonably well in both normal and highly athletic modern humans (Ruff, 2000; Jasuga et al., 2004). The present study shows that weight could be correlated with height and with BMI in Nigerian school children of Gbagyi Abuja. This shows that the higher the height of an individual, the lower the BMI and the higher the athletic performance according to Ruff, (2000); and Munoz et al., (2000).

Estimation of height using various physical measurements has been attempted by many researchers but the one variable that proves to be consistently reliable in the estimation of height is the hand length (Shintaku and Funiyay, 1990; Kanchan et al., 2010). The result from the present study shows that hand length can be used to predict height, together with age, weight and BMI. The present study shows the parameters used to determine height can also be used to determine hand length because there was a 2-tailed significant correlation between hand length and age, weight, height and BMI in both male and female Nigerian school children of Gbagyi tribe of Abuja.

Analysis of genetically disparate population reveals a clear pattern of sexual dimorphism, with women consistently having smaller hand, proportionate to stature than men (Saxena, 1984; Lundy and Feldsman, 1987). Therefore while varying in degree across populations in general; women have proportionately shorter hands than men but results from the present study show that males have shorter hand length than females which disagrees with the established pattern of men having longer hand length than women according to Quamra et al., (1980), Robbins (1986), Davis (1990), Giles and Vallandigham (1991), Barker and Schever (1998), Ozaslan et al, (2003). This could be as a result that the study was carried out with underage children of ages between 5-10 years in Nigerian children of Gbagyi tribe of Abuja. Scientifically it is known that a female child grows faster than a male child which could indicate that a female child have longer hand length than the male children.

The present study tried to create specific regression equations which could help in prediction of heights of Nigerian school children of Gbagyi tribe of Abuja. The equation for estimating height from hand length measurement of school children of Gbagyi tribe of Abuja Nigeria differs from those presented by Bhartnagar et al. (1984), who carried out studies among the Punja male children. This could be due to the differences in the average values of parameters studied. The differences could also be due to the different methods and parameters used in the present study. 


\section{Macrothink}

\section{Conclusion}

The results from the present study indicated that hand length is a proxy indicator for height when it is difficult or not possible to measure height directly, and also other variables such as age, weight and BMI stand as indicator for predicting height among Gbagyi school children of Abuja in Nigeria.

\section{References}

Amirsheybani H. R., Crecelius G. M., Timothy N. H., Pfeiffer M., Saggers G. C., \& Manders E.K., (2000). The natural history of growth of hand. Part I: Hand area as a percentage of body surface area. Plastic and Reconstructive Surgery, 107(3), 726-733. http://dx.doi.org/10.1097/00006534-200103000-00012

Amirsheybani H. R., Crecelius G. M., Timothy N. H., Pfeiffer M., Saggers G. C., \& Manders E.K. (2001). The natural history of growth of hand. Part II: Hand length as a treatment guide in paediatric trauma patients. Journal of trauma, 49, 457-460. http://dx.doi.org/10.1097/00005373-200009000-00012

Anitie H. (2007). Worldwide variation in human growth. 4, 67-68. Cambridge University Press.

Auerbach B. M., \& Ruff C. B., (2004). Human body mass estimation: a comparison of morphometric and mechanical methods. American Journal of physical anthropology, 125, 331-342. http://dx.doi.org/10.1002/ajpa.20032

Barker S. L., \& Schever J. L., (1998). Predictive values of human hand and foot prints in a forensic context. Med Sci Law, 38, 341-346.

Bidmos, M. A., (2006). A statuer reconstruction from the calcaneus of south Africans of European descent. Journal of clinical and forensic medicine, 13, 247-252. http://dx.doi.org/10.1016/j.jcfm.2005.11.010

Bidmos, M. A., (2009). Evaluation of accuracy of direct and indirect methods in stature reconstruction.

Bhatnagar, D., Thapar,S., \& British, M., (1984). Identification of personal height from the somatometry of the hands in Punjabi males. Forensic Science International, 24, 137-141. http://dx.doi.org/10.1016/0379-0738(84)90093-8

Boldsen, J., (1984). A statistical evaluation of the basis for predicting stature from lengths of long bones in European populations. American Journal of physical Anthropology, 65, 305-311. http://dx.doi.org/10.1002/ajpa.1330650310

Davis K. T., (1990). The foot length and hand length to stature ratio. A study of racial variance. MA thesis, Department of Anthropology, Texas Tech University, Lubbock, TX.

De Mendonca, M. C., (2000). Estimation of height from lengths of long bones in a Portuguese adult population. American Journal of Physical Anthropology, 112, 39-48. http://dx.doi.org/10.1002/(SICI)1096-8644(200005)112:1<39::AID-AJPA5>3.0.CO;2-\# 


\section{$\triangle$ Macrothink}

Journal of Biology and Life Science ISSN 2157-6076 2013, Vol. 4, No. 2

Duyar I. \& Pelin C., (2003). Body height estimation based on tibia length in different stature groups. American Journal of Physical Anthropology, 122, 23-27. http://dx.doi.org/10.1002/ajpa.10257

Duyar I., Pelin C., \& Zagyapan R. (2006). A new method of stature estimation for forensic anthropological application. Anthropological Science International, 114, 23-27. http://dx.doi.org/10.1537/ase.041217

Ebite M. N., S. T., \& Frisher K. R. (2000). Predicting stature through handlength. Journal of crime and criminalistic, 52, 23-27.

Fessler D. M T., Haley K. J., \& Lai R.D. (2005). Sexual dimorphism in hand length proportionate to stature. Ann Hum Biol, 32(1), 44-59. http://dx.doi.org/10.1080/03014460400027581

Gauld R. F., \& Rakhir S. M. (20O4). The nutritional status of disabled children: a cross-sectional survey. Eur. J Clin Nutr, 53(12), 915-9.

Gauld, R. F. \& Rakhir S. M. (1996). The prediction of stature from handlength. Journal of crime and criminalistic, 8, 79-81.

Giles E., \& Vallandigham P. H. (1991). Height estimation from foot, hand, and shoe length, $J$. of Forensic Science, 36, 18.

Hauser R., Smolinski J., \& Gos T. (2005). The estimation of stature on the basis of measurements of femur. Forensic Science International, 147, 181-184. http://dx.doi.org/10.1016/j.forsciint.2004.09.070

Iscan M. Y. (1988). Rise of forensic anthropology. Year Book of Physical Anthropology, 31, 203-230. http://dx.doi.org/10.1002/ajpa.1330310510

Iscan, M. Y. (2001). Editorial: Global Forensic anthropology in the $21^{\text {st }}$ century. Forensic Science International, 117, 1-6. http://dx.doi.org/10.1016/S0379-0738(00)00433-3

Jalzem, P. F, \& Gledhill R. B. (1993). Predicting height from limb measurement. Journal of Paediatrics and Orthopaedics, 13(6), 761-65. http://dx.doi.org/10.1097/01241398 $-199311000-00014$

Jasuga O. P, Singh J, \& Jain M. (2004). Estimation of stature from hand, foot and shoe measurement by multiplication factors: A reviewed attempt. Forensic Science International, 50, 203-215. http://dx.doi.org/10.1016/0379-0738(91)90152-9

Kanchan T., Krishan K, Sharma A, \& Menezes RG. (2010). A study of correlation of hand and foot dimensions for personal identification in mass disasters. Forensic Science International, 199, 112-116. http://dx.doi.org/10.1016/j.forsciint.2010.03.002

Krishan K., \& Sharma, A. (2007). Estimation of stature from dimension of hands and feet in North Indian Population. Journal of forensic and Legal Medicine, 14, 327-332. http://dx.doi.org/10.1016/j.jcfm.2006.10.008 


\section{Al Macrothink}

Journal of Biology and Life Science ISSN 2157-6076 2013, Vol. 4, No. 2

Lundy J. K., \& Feldesman M. R. (1987). Revised equations for estimating living stature from long bone of the South African Negro. South Africa Journal of Forensic Science. 83, 54-55.

Mauthausen K., \& Gusen, Y. R. (1959). Estimation of actual individual height during the exhumation of the remains of the former concentration camps. Journal of Forensic Science, 3 , 533-537.

Menezes B., \& Khany M., (1998). Estimation of stature from length of sternum in South Indian males. Forensic Science International, 125, 141-148.

Munoz J. I., Luiares-Iglesias M. J., Suarez-Penaranda, J. M., Mayo, M., Miguens, X. \& Roriquez-Calvo, M. S. (2000). Stature estimation from radiographically determined long bone length in a Spanish population sample. Journal of Forensic Scince. 46, 363-366.

Nath, S., Dayal, N. \& Chandara, N. S. (1998). Reconstruction of stature using percutaneous lengths of forearm bones among Mundas of Midnapore district. Journal of West Bengal Human Biology, 37, 170-175.

Ozaslan A., Iscan M. Y., Ozaslan I., \& Tugcuh. Kocs, (2003). Estimation of stature from body parts. Forensic Sci Int. 132, 40-45. http://dx.doi.org/10.1016/S0379-0738(02)00425-5

Quamra SR, Jit I, \& Deodhar S. D. (1980). A model for reconstruction of height from foot and hand measurements in an adult population of North West Indian. Indian J. Med Res 71, 77-83.

Reeves S. L, Varakamin C \& Henry C. J. (1996). The relationship between limb measurement and height with special reference to gender and ethnicity. European Journal of Clinical Nutrition, 50(6), 398-400.

Robbins LM. (1986). Estimation of height and weight from size of foot prints. Journals Forensic Science, 31, 143-152.

Ruff C. B. (2000). Body mass prediction from skeletal frame size in elite athletes. American Journal of Physical Anthropology, 113(4), 507-517. http://dx.doi.org/10.1002/1096-8644(200012)113:4<507::AID-AJPA5>3.0.CO;2-F

Saxena SK., (1984). Study of correlations and estimation of stature from hand length, hand breadth and sole length. Anthropol Anz. 42(2), 27, 1-6.

Shintaku K., \& Furuyay. (1990). Estimation of stature based on the proximal phalangeal length of Japanese women's hand. JUEOH. 12(2), 215-219.

Thakur SD., \& Rai KS. (1987). Determination of stature from hand measurement. Medicine Science and Law, 78, 25-28.

Trotter, M. \& Glesser, G. C. (1958). Are evaluations of estimation of stature based on measurements of stature taken during life and of long bones after death, American Journal of Physical Anthropology, 16(1), 79-123. http://dx.doi.org/10.1002/ajpa.1330160106

WHO. (1995). Physical status, the use and interpretation of athropometrics. Report of a WHO Expert Committee Technical Report Series No 854, Geneva. 


\section{Macrothink}

Yyagi A. K, Kohli A, Yerma SK \& Aggarwal BB. (1999). Correlation between stature and finger length, Int.J.Med. Toxicol and Legal Med, 1, 20-22.

\section{Copyright Disclaimer}

Copyright reserved by the author(s).

This article is an open-access article distributed under the terms and conditions of the Creative Commons Attribution license (http://creativecommons.org/licenses/by/3.0/). 